\title{
The Nature and Extent of Online Marketing by Big Food and Big Alcohol During the COVID-19 Pandemic in Australia: Content Analysis Study
}

Florentine Martino ${ }^{1}$, PhD; Ruby Brooks ${ }^{1}$, BNut (Hons); Jennifer Browne ${ }^{1}, \mathrm{PhD}$; Nicholas Carah ${ }^{2}$, PhD; Christina Zorbas $^{1}, \mathrm{PhD}$; Kirstan Corben ${ }^{3}$, MHP; Emma Saleeba ${ }^{3}$, MPH; Jane Martin ${ }^{4}$, MPH; Anna Peeters ${ }^{1}$, PhD; Kathryn Backholer $^{1}, \mathrm{PhD}$

\footnotetext{
${ }_{1}^{1}$ Deakin University, Geelong, Australia, Global Obesity Centre, Institute for Health Transformation

${ }^{2}$ School of Communication and Arts, The University of Queensland, Brisbane, Australia

${ }^{3}$ Victorian Health Promotion Foundation, Melbourne, Australia

${ }^{4}$ Obesity Policy Coalition, Melbourne, Australia
}

\section{Corresponding Author:}

Kathryn Backholer, PhD

Deakin University

Global Obesity Centre

Institute for Health Transformation

1 Gheringhap Street

Geelong, 3220

Australia

Phone: 61392443836

Email: kathryn.backholer@deakin.edu.au

\begin{abstract}
Background: Emerging evidence demonstrates that obesity is associated with a higher risk of COVID-19 morbidity and mortality. Excessive alcohol consumption and "comfort eating" as coping mechanisms during times of high stress have been shown to further exacerbate mental and physical ill-health. Global examples suggest that unhealthy food and alcohol brands and companies are using the COVID-19 pandemic to further market their products. However, there has been no systematic, in-depth analysis of how "Big Food" and "Big Alcohol" are capitalizing on the COVID-19 pandemic to market their products and brands.

Objective: We aimed to quantify the extent and nature of online marketing by alcohol and unhealthy food and beverage companies during the COVID-19 pandemic in Australia.

Methods: We conducted a content analysis of all COVID-19-related social media posts made by leading alcohol and unhealthy food and beverage brands $(n=42)$ and their parent companies $(n=12)$ over a 4-month period (February to May 2020) during the COVID-19 pandemic in Australia.

Results: Nearly $80 \%$ of included brands and all parent companies posted content related to COVID-19 during the 4-month period. Quick service restaurants (QSRs), food and alcohol delivery companies, alcohol brands, and bottle shops were the most active in posting COVID-19-related content. The most common themes for COVID-19-related marketing were isolation activities and community support. Promotion of hygiene and home delivery was also common, particularly for QSRs and alcohol and food delivery companies. Parent companies were more likely to post about corporate social responsibility (CSR) initiatives, such as donations of money and products, and to offer health advice.

Conclusions: This is the first study to show that Big Food and Big Alcohol are incessantly marketing their products and brands on social media platforms using themes related to COVID-19, such as isolation activities and community support. Parent companies are frequently posting about CSR initiatives, such as donations of money and products, thereby creating a fertile environment to loosen current regulation or resist further industry regulation. "COVID-washing" by large alcohol brands, food and beverage brands, and their parent companies is both common and concerning. The need for comprehensive regulations to restrict unhealthy food and alcohol marketing, as recommended by the World Health Organization, is particularly acute in the COVID-19 context and is urgently required to "build back better" in a post-COVID-19 world.
\end{abstract}


(JMIR Public Health Surveill 2021;7(3):e25202) doi: 10.2196/25202

\section{KEYWORDS}

alcohol; food and beverage; COVID-19; marketing; social media

\section{Introduction}

In March 2020, the World Health Organization declared a global COVID-19 pandemic, which is caused by the virus SARS-CoV-2 [1]. People over the age of 60 years and those with underlying noncommunicable diseases, such as cancer, obesity, cardiovascular disease, and diabetes, are at higher risk of developing severe illness from COVID-19 [2]. These conditions impair the immune system and the ability to fight off viruses [3]. Consumption of alcohol and ultraprocessed foods are leading risk factors for these underlying conditions [4]. Additionally, heavy alcohol consumption, both short and long term, is known for its direct immunosuppressive effects [5].

The COVID-19 pandemic is also having serious consequences for mental health. A recent poll demonstrated that the pandemic has negatively impacted the mental health of $48 \%$ of parents and $36 \%$ of children in Australia [6]. Well-known coping mechanisms for dealing with stress and negative emotions include excessive consumption of alcohol [7,8] and overeating of unhealthy, highly palatable foods [9]. Indeed, evidence shows that population consumption of unhealthy foods and excessive alcohol intake increases after mass traumas, such as global financial crises, terrorism, and natural disasters [7,10,11]. This may, in turn, exacerbate mental and physical ill-health. For example, alcohol use is associated with increased reporting of interpersonal and domestic violence incidents [12]. Similarly, unhealthy diets are associated with poor mental health outcomes for adults and children, such as depression [13] as well as anxiety and mood disorders [14]. Building healthy populations resilient to the ongoing threat of COVID-19 and potential future public health threats will require a concerted effort to reduce obesity, unhealthy dietary intake, and excessive alcohol consumption across the population [15].

Marketing of unhealthy foods and beverages and alcohol influences attitudes, preferences, expectations, and consumption of these products over the life course [16]. With the rise of social media and other digital platforms, marketing is omnipresent, increasingly targeted, immersive, and engaging [17]. Consumption of alcohol and unhealthy foods and beverages is frequently portrayed by the alcohol and food industries as fun and harmless $[18,19]$. Global examples of marketing by these industries during the COVID-19 pandemic suggest that unhealthy food and alcohol brands and companies are capitalizing on the pandemic to promote their products, market corporate social responsibility (CSR), pursue partnerships, and shape policy environments [20]. The alignment of brands and companies with a social or health issue, known as cause marketing, is a subset of CSR business practices [21]. Cause marketing is used to build goodwill and to enhance public perceptions of the brand [22]. Social media platforms are ideal platforms to promote CSR activities, as interaction with consumers is high, maximizing opportunities to expand audience reach [23]. Regardless of whether or not cause marketing has positive social impacts, it is counterproductive if companies promote products that contribute to the problems they purport to solve. For example, alcohol brands have been found to "pinkwash" their products by aligning themselves with the pink ribbon of the breast cancer awareness campaign, which is paradoxical, as alcohol is an established risk factor for breast cancer [24].

No study to date has systematically and comprehensively examined if "Big Alcohol" and "Big Food" are capitalizing on the COVID-19 pandemic to increase sales by "COVID-washing" their online posts. This study aimed to examine the nature and extent of COVID-19-related online posts by leading alcohol and unhealthy food and beverage brands and their parent companies in Australia over 4 months (February to May 2020) during the COVID-19 pandemic.

\section{Methods}

\section{Study Design}

Similar to previous studies that investigated marketing by Big Food and Big Alcohol on social media [25,26], we conducted a content analysis of the public accounts on social media platforms of leading alcohol brands, unhealthy (ie, energy-dense and nutrient-poor) food and beverage brands, and their parent companies. Content analysis is "a research technique for making replicable and valid inferences from texts (or other meaningful matter) to the contexts of their use" [27]. All COVID-19-related posts were retrospectively extracted in June 2020 for a 4-month time period during the first wave of the COVID-19 pandemic in Australia, with data collected between February 1 and May 31, 2020. During these 4 months, various actions to limit the spread of COVID-19 were implemented in Australia, including public health orders to stay at home. As this research only involved analysis of publicly available social media accounts, institutional ethics approval was not required.

\section{Selection of Brands and Companies}

We selected the top five brands in Australia and their parent companies across the following categories: (1) confectionery, (2) snacks, (3) soft drinks, (4) quick service restaurants (QSRs), (5) food delivery services, (6) beer, (7) wine, (8) spirits, (9) ready-to-drink (RTD) alcoholic beverages, (10) alcohol retailers, and (11) alcohol delivery services (see Multimedia Appendix 1). These Australian brands were selected based on Australian market share (ie, sales) [28].

Some of the top five of RTD alcoholic beverage and spirit brands overlapped (eg, Jim Beam had an RTD alcoholic beverage and a spirit in the top five), and some of the top five bottle shops and alcohol delivery companies overlapped (eg, Dan Murphy's was in top five of both categories). We combined these categories when presenting results. Brands that did not sell ultraprocessed foods and beverages according to the NOVA 
classification [29], such as dairy brands, were excluded and replaced by the brand with the next largest market share.

\section{Selection of Social Media Platforms}

We selected brands' and companies' official public accounts on the following social media platforms, where available: Facebook, Instagram, YouTube, and Twitter. These four social media platforms were chosen for the following reasons:

1. Facebook, Instagram, and YouTube are the most frequently used platforms by Australians, and Twitter is an important platform for public relations communication from major brands and corporations.

2. These platforms are commonly used by large brands and companies for both advertising and public relations.

3. Facebook, including its subsidiary Instagram, and Google, including its subsidiary YouTube, constitute an advertising duopoly. The Australian Consumer and Competition Commission estimates that Facebook and Google receive two-thirds of the online advertising spend in Australia [30].

We sampled the social media accounts that were most likely to target Australian audiences. Therefore, only the Australian accounts of brands were included. Parent companies, on the other hand, are often global entities with multiple brands in their portfolio and often did not have a local social media presence in Australia. If this was the case, international accounts were selected, where available. Occasionally, brands and parent companies used the same accounts (eg, Arnott's, Lindt, and Uber Eats), in which case the data were only captured in the brands analysis. Finally, we excluded social media accounts that had not been active during the prior 12 months (ie, since February 1, 2019).

\section{Data Collection}

For each social media platform, we collected data on the number of followers, the total number of posts, and details of COVID-19-related posts that brands and companies shared using their public social media accounts. The date of these posts, the product marketed, and number of likes, views, and shares - at least one week after sharing the post—were recorded in a standardized template.

COVID-19-related posts were included if they directly or indirectly referred to the COVID-19 pandemic or issues pertaining to COVID-19 (see Figure 1), such as lockdown and social distancing. Indirect marketing included posts where the only relationship to COVID-19 was the addition of hashtags (eg, \#workfromhome, \#quarantinecooking, and \#quarantini).

Figure 1. Examples of posts directly (left) and indirectly (right) related to the COVID-19 context.

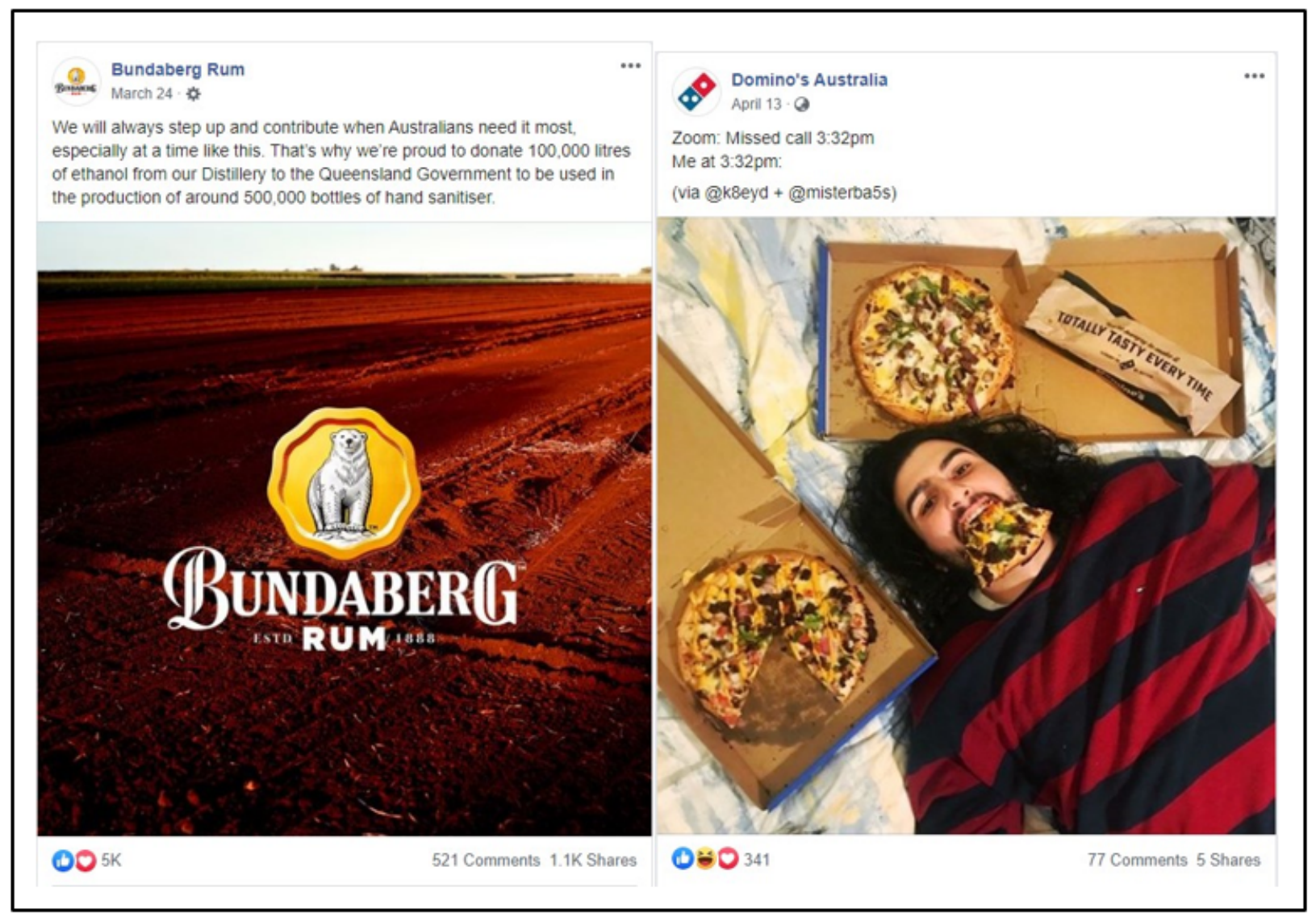

Only official brand- and company-generated posts on their social media accounts or channels were included in our analysis. For Facebook, we collected posts and reposts, including photos, videos, and events; for Instagram, we collected posts, pinned stories, and hashtag promotions in account bios; for YouTube, we collected videos; and finally, for Twitter, we collected tweets and retweets. We did not include user-generated content. For all four social media platforms, we collected the number of followers or channel subscribers (see Table 1). 
Table 1. Social media followers by platform and Australian brand account during the first week of May 2020.

\begin{tabular}{|c|c|c|c|c|}
\hline \multirow[t]{2}{*}{ Brands } & \multicolumn{4}{|c|}{ Followers on social media platforms, $n$} \\
\hline & Facebook & Instagram & YouTube & Twitter \\
\hline \multicolumn{5}{|l|}{ Confectionery } \\
\hline Cadbury & $16,704,000$ & 24,500 & 3250 & 15,100 \\
\hline Allen's & 378,000 & 11,500 & 513 & $<100$ \\
\hline Darrell Lea & 128,000 & 14,600 & $<100$ & 1000 \\
\hline Lindt & $7,196,000$ & 14,000 & 1030 & $\mathrm{~N} / \mathrm{A}^{\mathrm{a}}$ \\
\hline \multicolumn{5}{|l|}{ Snacks } \\
\hline Arnott's & 93,700 & 13,900 & 3350 & 2800 \\
\hline Peters & 42,200 & N/A & 267 & N/A \\
\hline Magnum & $12,412,000$ & N/A & 3400 & N/A \\
\hline Smith's & 161,900 & 600 & 3400 & N/A \\
\hline \multicolumn{5}{|l|}{ Soft drinks } \\
\hline Coca-Cola & $1,059,000$ & 45,000 & 7450 & 6200 \\
\hline Pepsi Max & $37,511,000$ & 1200 & 2990 & 800 \\
\hline Schweppes & 85,000 & 4100 & 367 & 1200 \\
\hline Kirks & 130,000 & 200 & $<100$ & N/A \\
\hline \multicolumn{5}{|l|}{ Quick service restaurants } \\
\hline McDonald's & $80,537,000$ & 156,000 & 22,900 & 32,800 \\
\hline $\mathrm{KFC}$ & $55,241,000$ & 154,000 & 9510 & 29,600 \\
\hline Hungry Jack's & 664,000 & 61,200 & 4600 & 11,800 \\
\hline Domino’s Pizza & $1,126,000$ & 97,400 & 4120 & 37,700 \\
\hline Subway & 809,600 & 18,100 & 2460 & 9300 \\
\hline \multicolumn{5}{|l|}{ Food delivery services } \\
\hline Uber Eats & $2,767,000$ & 49,700 & N/A & N/A \\
\hline Deliveroo & 751,000 & 21,100 & $<100$ & 600 \\
\hline DoorDash & N/A & N/A & N/A & N/A \\
\hline Menulog & 118,000 & 6800 & 1350 & 3700 \\
\hline \multicolumn{5}{|l|}{ Beer } \\
\hline XXXX Gold & 426,000 & 13,200 & 31,500 & 300 \\
\hline Corona Extra & $15,119,000$ & 34,800 & 15,800 & 700 \\
\hline Carlton Premium Dry & 191,000 & 17,600 & 2140 & 900 \\
\hline Victoria Bitter & 154,000 & 33,000 & 1100 & 1900 \\
\hline Great Northern Original Lager & 121,000 & 31,900 & 800 & N/A \\
\hline \multicolumn{5}{|c|}{ Spirits and ready-to-drink alcoholic beverages } \\
\hline Smirnoff Red & $14,168,000$ & 6800 & 440 & 300 \\
\hline Johnnie Walker Red Label & $14,901,000$ & N/A & 1410 & N/A \\
\hline Jim Beam & $3,205,000$ & N/A & 600 & 300 \\
\hline Jack Daniel's & $17,304,000$ & 9000 & 1060 & 5700 \\
\hline Bundaberg & 372,000 & 22,200 & 1640 & 1700 \\
\hline Canadian Club & 283,000 & 12,900 & 200 & 700 \\
\hline Woodstock \& Cola & 60,100 & 2000 & $<100$ & N/A \\
\hline Wine & & & & \\
\hline
\end{tabular}




\begin{tabular}{|c|c|c|c|c|}
\hline \multirow[t]{2}{*}{ Brands } & \multicolumn{4}{|c|}{ Followers on social media platforms, $n$} \\
\hline & Facebook & Instagram & YouTube & Twitter \\
\hline De Bortoli & 20,000 & 10,000 & 306 & 8200 \\
\hline McWilliam's & 14,800 & 12,700 & $<100$ & 2700 \\
\hline Stanley Wines & N/A & N/A & N/A & N/A \\
\hline Jacob's Creek & 853,000 & 27,200 & 1430 & 5000 \\
\hline Berri Estates & $<100$ & N/A & N/A & N/A \\
\hline \multicolumn{5}{|c|}{ Bottle shops and alcohol delivery services } \\
\hline BWS & 269,000 & 11,600 & N/A & N/A \\
\hline Liquorland & 152,000 & 3400 & $<100$ & 1400 \\
\hline Dan Murphy's & 477,000 & 42,500 & 6850 & 9300 \\
\hline Cellarbrations & 60,200 & 1000 & $<100$ & 200 \\
\hline IGA Plus Liquor & 13,600 & N/A & N/A & N/A \\
\hline Shop My Local & $<100$ & $<100$ & N/A & N/A \\
\hline Jimmy Brings & 16,400 & 5179 & Not displayed ${ }^{\mathrm{b}}$ & 200 \\
\hline
\end{tabular}

${ }^{\mathrm{a}}$ N/A: not applicable; the brand did not have an Australian social media account or had not posted since February 2019 and was excluded from the analysis.

${ }^{\mathrm{b}}$ This brand did have an active platform, YouTube in this case; however, the number of subscribers was not displayed. This account was included in the analysis.

\section{Data Analysis}

We developed a coding framework based on an initial analysis of COVID-19-related posts by a subset of brands in our sample. Three investigators identified COVID-19-related themes used in social media posts by the top brand and company in each category. These initial themes were discussed with the research team in order to develop a coding framework that could be applied across all sampled social media accounts. The framework continued to develop iteratively as additional themes were identified in the data (see Table 2).

Three researchers extracted and coded the social media posts. Every individual post was independently extracted and coded by one researcher (RB or JB), and a subsample (20\%) of all posts by the top brands in every product category was cross-checked for consistency of data extraction and coding by a third researcher (FM). Discrepancies in data extraction and coding were discussed between researchers and, where necessary, through consultation with a fourth researcher (KB) until consensus was reached. Because there were very few discrepancies in coding, we did not continue this process for the remaining brands. Similarly, any unclear posts and how these should be coded were discussed between the three coders and the senior member of the research team (KB) throughout the analysis.

Once all the COVID-19-related posts had been identified and coded according to the framework, we calculated the frequency with which each COVID-19-related theme was used by each brand and company and across product categories (see Table 2). 
Table 2. COVID-19-related marketing themes.

\begin{tabular}{ll}
\hline COVID-19 theme & Description \\
\hline Trading or event updates & $\begin{array}{l}\text { Practical updates around trading hours, opening or closing } \\
\text { of stores, and events during the COVID-19 pandemic, ex- } \\
\text { cluding delivery }\end{array}$
\end{tabular}

Home delivery or take away in lockdown period

Hygiene or zero contact

Community support or feeling

Applauding health staff or essential workers

Donations

Isolation activities

Consumption helps with coping with COVID-19

Supporting local business or trading partners

Mentions of home delivery or take away options during the COVID-19 pandemic (eg, no need to leave the house and staying at home during difficult times)

References to reducing chances of virus spread through hygiene practices when preparing food or handling food and drinks, social distancing by employees and customers, and extra cleaning and disinfecting (eg, contactless, zero contact, and keeping community safe)

References to standing together during these challenging, unprecedented, or unexpected times and/or the brand or company being there to support consumers and we are all in this together

Referencing or thanking essential workers, health workers, frontline workers, etc, including discounts for these workers

References to large-scale product or financial donation

Suggestions for things to do while in isolation that include brand use or promotion

References to consumption making consumers feel better or to consumers deserving the advertised product

Suggests consumers should support local businesses, or announcements that the brand or company supports local businesses or their trading partners

Health advice, including mental health

Posts include health, including mental health, advice with reference to COVID-19

Production of sanitizing products due to the coronavirus, making it difficult for many com munities to provide for their families. Our frontline healthcare workers are overworked as we overcome this pandemic. To help share comfort and nutrition, \#TeamMDLZ \#Philippines has shared P12MM worth of snack products to communities and frontline healthcare workers, working with 40+ organizations. \#StrongerTogether" (Mondelez-Facebook, international parent company)

“Beam Suntory and Southern Glazer’s Wine \& Spirits $\$ 1$ million donation will provide resources and financial aid to workers affected by mandated closures amidst the COVID-19 pandemic" (Beam Suntory-Facebook, international parent company)

Example

"We're still open! As you've just heard from our PM, no ime, visit us in-sty to ofl-licence venues. So take your phys" (Dan Murphy's-Twitter, local brand)

"Working from home? You can still enjoy your Macca's tactless McDelivery. We'll deliver to you." (McDonald's-Instagram, local brand)

"We won't let anything get in the way of you and your sub, ot even a little <-- social distancing --> Come see us inyou stay about five Subway Footlong® subs apart" (Subway-Facebook, local brand)

'Connect with your mates online and we'll get through this together, with a GOLD in hand" (XXXX Gold—Facebook, local brand)

"\#StayHome and get your bake on this week with this tantalising TeeVee Snacks Caramel Slice! A deliciously indulgent snack that will really hit the sweet spot. https://bit.ly/3bqGIxd" (Arnott's—Facebook, local brand)

"Jump on our site to organise drinks for your staff in 3 simple steps. Then jump on Zoom and crack a cold one together - a bit of normalcy is great for team morale!" (Jimmy Brings-Instagram, local brand)

"This is a very challenging time for many of our customers As part of our ongoing support, Coca-Cola Amatil has established a free 24-hour customer support and counselling service for our customers who are struggling with the unprecedented impact of COVID-19. The Coca-Cola Amatil Customer Support Line is run by Assure, a trusted Amatil partner. The 24/7 support service offers confidential counselling and financial coaching and is available to all Amatil customers completely free of charge, in the strictest confidence. Contact your Coca-Cola Amatil representative for all the details." (Coca-Cola Amatil—Facebook, local parent company)

"Touching multiple surfaces, then our faces, is one of the most common causes of infection. Find out how bleach can clean and protect your home from our expert Suresh Nadakatti." (Unilever-Twitter, international parent company)

"\#ICYMI: Brown-Forman and others in the spirits industry convert distilling operations to produce sanitizer to combat the COVID-19 health crisis. https://bddy.me/2y3FNEb" (Brown Forman-Twitter, international parent company) 


\begin{tabular}{lll}
\hline COVID-19 theme & Description & Example \\
\hline $\begin{array}{l}\text { Maintaining an essential } \\
\text { product supply chain }\end{array}$ & $\begin{array}{l}\text { References to supply chains being maintained, ensuring } \\
\text { consumers' needs are met }\end{array}$ & $\begin{array}{l}\text { "Our nine factories across Australia and New Zealand are } \\
\text { hard at work making product. Our dedicated teams are do- } \\
\text { ing their best to bring your favourite Nestlé food and bev- } \\
\text { erage products to a store near you. Look after yourself and } \\
\text { each other out there! } \bullet \text { Nestlé" (Nestlé-Facebook, inter- } \\
\text { national parent company) }\end{array}$ \\
\hline
\end{tabular}

\section{Results}

\section{Food and Alcohol Brands}

After excluding brands and services without Australian accounts in Australia, 42 brands were included in the analysis. Table 3 shows that most brands had low or no activity on YouTube and Twitter ( $<20$ posts over 4 months), with a few exceptions such as Jimmy Brings on YouTube (24 posts; 0\% COVID-19 related) and Domino's on Twitter (24 posts; 38\% [9/24] COVID-19 related). The number of account followers (see Table 1) shows that brands generally have the greatest social media followings on Facebook and Instagram. For example, McDonald's Australia had 80,537,000 followers on Facebook, 156,000 on Instagram, 23,000 on YouTube, and 33,000 on Twitter.

Most brands $(33 / 42,79 \%)$ posted content that related to the COVID-19 pandemic. A total of 916 COVID-19-related posts out of 2796 posts $(32.8 \%)$ were identified. Engagement by followers in terms of likes, shares, and views was substantial and varied greatly between brands and type of content (see Table 3 ), with more active accounts generating more interactions, in general, as did videos regardless of platform. The product categories with the highest proportions of total posts related to COVID-19 were bottle shops and alcohol delivery (231/619, $37.3 \%)$, QSRs $(353 / 915,38.6 \%)$, food delivery $(52 / 142,36.6 \%)$, beer $(86 / 226,38.1 \%)$, spirits and RTD alcoholic beverages $(34 / 121,28.1 \%)$, and wine $(83 / 261,31.8 \%)$ (see Table 3$)$. COVID-19-related marketing activity was very low or nonexistent for brands within the snacks and soft drink categories. Arnott's was the most active in its category (ie, snacks), with 18 COVID-19-related posts on Facebook and Instagram $(18 / 92,20 \%)$ across the 4-month period.

Specific brands that were most actively posting COVID-19-related content were Domino's and Dan Murphy's, with both brands posting more than 100 COVID-19-related posts across the four social media platforms (Domino's: 231/623, 37.1\% of total posts; Dan Murphy's: 119/253, $47.0 \%$ of total posts) during the 4-month period. 
Table 3. COVID-19-related marketing on social media platforms by the top Australian unhealthy food, beverage, and alcohol brands over 4 months (February to May 2020).

\begin{tabular}{|c|c|c|c|c|c|c|}
\hline \multirow[t]{2}{*}{ Brands } & \multicolumn{5}{|c|}{ COVID-19-related posts on Australian brands' social media accounts, $\mathrm{n} / \mathrm{N}(\%)$} & \multirow{2}{*}{$\begin{array}{l}\text { Shares, views, and likes per } \\
\text { COVID-19 post, mean (SD), } \\
\text { range }\end{array}$} \\
\hline & Facebook & Instagram & YouTube & Twitter & Total & \\
\hline \multicolumn{7}{|l|}{ Confectionery } \\
\hline Cadbury $^{\mathrm{a}}$ & $10 / 48(21)$ & $3 / 14(21)$ & $\mathrm{N} / \mathrm{A}^{\mathrm{b}}$ & No posts ${ }^{\mathrm{c}}$ & $13 / 62(21)$ & 590 (772), 14-2569 \\
\hline Allen's & $1 / 7(14)$ & N/A & $0 / 1(0)$ & N/A & $1 / 8(14)$ & $43^{\mathrm{d}}$ \\
\hline Darrell Lea & $7 / 50(14)$ & $6 / 44(14)$ & $2 / 7(29)$ & N/A & $15 / 101(14.9)$ & $6528(19,255), 126-76,000$ \\
\hline Lindt & $11 / 86(13)$ & $16 / 125(12.8)$ & No posts & N/A & $27 / 211(12.8)$ & 242 (269), 24-1114 \\
\hline Total & 29/191 (15.2) & $25 / 183(13.7)$ & $2 / 8(25)$ & $-^{\mathrm{e}}$ & $56 / 382(14.7)$ & Not calculated ${ }^{\mathrm{f}}$ \\
\hline \multicolumn{7}{|l|}{ Snacks } \\
\hline Arnott's & $10 / 48(21)$ & $8 / 44(18)$ & No posts & No posts & $18 / 92(20)$ & 554 (637), 45-1874 \\
\hline Peters & $0 / 4(0)$ & N/A & N/A & N/A & $0 / 4(0)$ & - \\
\hline Magnum & $0 / 3(0)$ & N/A & No posts & N/A & $0 / 3(0)$ & - \\
\hline Smith's & $0 / 13(0)$ & N/A & No posts & N/A & $0 / 13(0)$ & - \\
\hline Total & $10 / 68(15)$ & $8 / 44(1)$ & - & - & $18 / 112(16.1)$ & Not calculated \\
\hline \multicolumn{7}{|l|}{ Soft drinks } \\
\hline Coca-Cola & $1 / 6(17)$ & $0 / 4(0)$ & $0 / 1(0)$ & No posts & $1 / 11(9)$ & $247^{\mathrm{d}}$ \\
\hline Pepsi Max & $2 / 4(50)$ & N/A & $0 / 1(0)$ & N/A & $2 / 5(40)$ & $29(7), 24-34$ \\
\hline Schweppes & $0 / 1(0)$ & $0 / 1(0)$ & No posts & N/A & $0 / 2(0)$ & - \\
\hline Kirks $^{\mathrm{g}}$ & N/A & N/A & N/A & N/A & N/A & - \\
\hline Total & $3 / 11(27)$ & $0 / 5(0)$ & $0 / 2(0)$ & - & $3 / 18(17)$ & Not calculated \\
\hline \multicolumn{7}{|c|}{ Quick service restaurants } \\
\hline McDonald's & $12 / 23(52)$ & $9 / 20(45)$ & $1 / 13(8)$ & $3 / 3(100)$ & $25 / 59(42)$ & $\begin{array}{l}29,387(131,637), 33- \\
660,977\end{array}$ \\
\hline $\mathrm{KFC}$ & $14 / 24(58)$ & $6 / 14(43)$ & $0 / 2(0)$ & No posts & $20 / 40(50)$ & 4061 (6136), 6-22,706 \\
\hline Hungry Jack's & $17 / 49(35)$ & $9 / 31(29)$ & $1 / 7(14)$ & 4/9 (44) & $31 / 96(32)$ & $3944(16,266), 6-91,384$ \\
\hline Domino's & $147 / 365(40.3)$ & $70 / 227(30.8)$ & $5 / 7(71)$ & $9 / 24(38)$ & $231 / 623(30.1)$ & 1028 (3649), 2-300,015 \\
\hline Subway & 29/61 (48) & $16 / 33(48)$ & $1 / 3(33)$ & No posts & $46 / 97(47)$ & $19,010(65,422), 25-355,044$ \\
\hline Total & $219 / 522(42.0)$ & $110 / 325(33.8)$ & $8 / 32(25)$ & $16 / 36(44)$ & $353 / 915(38.6)$ & Not calculated \\
\hline \multicolumn{7}{|c|}{ Food delivery services } \\
\hline Uber Eats & $3 / 7(43)$ & $12 / 18(67)$ & N/A & N/A & $15 / 25(60)$ & 588 (557), 19-1911 \\
\hline Deliveroo & $0 / 3(0)$ & $7 / 22(32)$ & No posts & $0 / 3(0)$ & $7 / 28(25)$ & 819 (419), 155-1506 \\
\hline DoorDash $^{\mathrm{g}}$ & N/A & N/A & N/A & N/A & N/A & - \\
\hline Menulog & $11 / 26(42)$ & $11 / 45(24)$ & $2 / 5(40)$ & $6 / 13(46)$ & $30 / 89(34)$ & 238 (768), $0-4223$ \\
\hline Total & $14 / 36(39)$ & $30 / 85(35)$ & $2 / 5(40)$ & $6 / 13(46)$ & $52 / 142(36.6)$ & Not calculated \\
\hline \multicolumn{7}{|l|}{ Beer } \\
\hline XXXX Gold & $7 / 16(44)$ & 4/9 (44) & $1 / 1(100)$ & N/A & $12 / 26(46)$ & 1073 (682), 265-2376 \\
\hline Corona Extra & $1 / 1(100)$ & $0 / 23(0)$ & No posts & N/A & $1 / 24(4)$ & $41^{\mathrm{d}}$ \\
\hline $\begin{array}{l}\text { Carlton Premi- } \\
\text { um Dry }\end{array}$ & $14 / 23(61)$ & N/A & N/A & N/A & $14 / 23(61)$ & 1448 (3395), 38-12,821 \\
\hline Victoria Bitter & $24 / 62(39)$ & $13 / 52(25)$ & N/A & N/A & $37 / 114(32.5)$ & 1198 (660), 221-2781 \\
\hline
\end{tabular}


Brands COVID-19-related posts on Australian brands' social media accounts, n/N (\%)
Shares, views, and likes per COVID-19 post, mean (SD), range

\begin{tabular}{|c|c|c|c|c|c|c|}
\hline & Facebook & Instagram & YouTube & Twitter & Total & \\
\hline $\begin{array}{l}\text { Great Northern } \\
\text { Original Lager }\end{array}$ & $6 / 8(75)$ & $14 / 29(48)$ & $2 / 2(100)$ & N/A & $22 / 39(56)$ & $19,461(64,807), 10-282,560$ \\
\hline Total & $52 / 110(47.3)$ & $31 / 113(27.4)$ & $3 / 3(100)$ & - & $86 / 226(38.1)$ & Not calculated \\
\hline \multicolumn{7}{|c|}{ Spirits and ready-to-drink alcoholic beverages (combined) } \\
\hline Smirnoff Red & $0 / 4(0)$ & No posts & N/A & N/A & $0 / 4(0)$ & - \\
\hline $\begin{array}{l}\text { Johnnie Walker } \\
\text { Red Label }\end{array}$ & No posts & N/A & No posts & N/A & No posts & - \\
\hline Jim Beam & $0 / 14(0)$ & $0 / 4(0)$ & $0 / 2(0)$ & N/A & $0 / 20(0)$ & - \\
\hline Jack Daniel's & $7 / 19(37)$ & $6 / 17(35)$ & N/A & N/A & $13 / 36(36)$ & 506 (482), 41-1546 \\
\hline Bundaberg & $6 / 13(46)$ & $6 / 11(55)$ & No posts & N/A & $12 / 24(50)$ & 1121 (1317), 265-5000 \\
\hline Canadian Club & $3 / 3(100)$ & $6 / 8(75)$ & $0 / 1(0)$ & N/A & $9 / 12(75)$ & 3044 (6427), 87-20,105 \\
\hline $\begin{array}{l}\text { Woodstock \& } \\
\text { Cola }\end{array}$ & $0 / 9(0)$ & $0 / 16(0)$ & N/A & N/A & $0 / 25(0)$ & - \\
\hline Total & $16 / 62(26)$ & $18 / 56(32)$ & $0 / 3(0)$ & - & $34 / 121(28.1)$ & Not calculated \\
\hline \multicolumn{7}{|l|}{ Wine } \\
\hline De Bortoli & $21 / 61(34)$ & $24 / 56(43)$ & $0 / 11(0)$ & $2 / 13(15)$ & $47 / 141(33.3)$ & 161 (154), 3-695 \\
\hline McWilliam's & $7 / 34(21)$ & $7 / 32(22)$ & N/A & N/A & $14 / 66(21)$ & $39(25), 9-84$ \\
\hline Stanley Wines ${ }^{\mathrm{g}}$ & N/A & N/A & N/A & N/A & N/A & - \\
\hline Jacob's Creek & $10 / 25(40)$ & $9 / 20(45)$ & $0 / 1(0)$ & N/A & $19 / 46(41)$ & 144 (164), $1-481$ \\
\hline Berri Estates & $3 / 8(38)$ & N/A & N/A & N/A & $3 / 8(38)$ & $23(23), 2-48$ \\
\hline Total & $41 / 128(32.0)$ & 40/108 (37.0) & $0 / 12(0)$ & $2 / 13(15)$ & $83 / 261(31.8)$ & Not calculated \\
\hline \multicolumn{7}{|c|}{ Bottle shops and alcohol delivery services (combined) } \\
\hline BWS & $34 / 77(44)$ & $34 / 55(68)$ & N/A & N/A & $68 / 132(51.5)$ & $213(376), 0-1657$ \\
\hline Liquorland & $3 / 15(20)$ & $3 / 24(13)$ & N/A & N/A & $6 / 39(15)$ & 85 (119), 6-317 \\
\hline Dan Murphy's & $75 / 100(75.0)$ & $36 / 135(26.7)$ & $4 / 14(29)$ & $4 / 4(100)$ & $119 / 253(47.0)$ & $\begin{array}{l}13,751(142,233), 2- \\
1,552,065\end{array}$ \\
\hline Cellarbrations & $0 / 10(0)$ & N/A & N/A & N/A & $0 / 10(0)$ & - \\
\hline $\begin{array}{l}\text { IGA Plus } \\
\text { Liquor }\end{array}$ & $1 / 11(9)$ & N/A & N/A & N/A & $1 / 11(9)$ & $39^{\mathrm{d}}$ \\
\hline Shop My Local & $1 / 31(3)$ & $0 / 21(0)$ & N/A & N/A & $1 / 52(2)$ & $3^{\mathrm{d}}$ \\
\hline Jimmy Brings & $14 / 39(36)$ & $19 / 50(38)$ & $0 / 24(0)$ & $3 / 9(33)$ & $36 / 122(29.5)$ & $148(360), 1-1792$ \\
\hline Total & $128 / 283(45.2)$ & $92 / 285(32.3)$ & 4/38 (11) & $7 / 13(54)$ & $231 / 619(37.3)$ & Not calculated \\
\hline
\end{tabular}

${ }^{\mathrm{a}}$ Cadbury represents two of the top five brands in the confectionery category: Cadbury and Cadbury Dairy Milk. Cadbury Dairy Milk was also in the top five brands within the snack category.

${ }^{b}$ N/A: not applicable; brand did not have an Australian social media account for this platform or had not posted since February 2019 and was excluded from analysis.

${ }^{\mathrm{c}}$ Brand did have an Australian social media account for this platform, but there were no posts of any kind during this period and, therefore, no COVID-19-related posts; percentage cannot be calculated because division by zero is undefined.

${ }^{\mathrm{d}}$ There was only 1 COVID-19-related post, so SD and range could not be calculated.

${ }^{\mathrm{e}}$ Could not be calculated because there were no COVID-19-related posts or no posts of any kind on these platforms, the brands did not use this social media platform, or the brands did not have an Australian social media account.

${ }^{\mathrm{f}}$ Grand means of shares, views, and likes per COVID-19 post within brand categories were not calculated, as there was a large variation between the brands in terms of number of followers.

${ }^{\mathrm{g}}$ This brand did not have any Australian accounts and was excluded from the analysis. 
The analysis of COVID-19-related posts (n=916) identified a broad range of themes used, with often more than one theme used per post, in particular when posting video content. Table 4 shows that, across all brands, the themes most consistently used were (1) isolation activities, which included suggestions and activities for people to do at home while in isolation (eg, cocktail recipes by BWS, online trivia nights organized by Dan Murphy's, and virtual parties by Domino's), and (2) community support.

Table 4. Proportion of COVID-19-related themes of social media posts by brand category.

\begin{tabular}{|c|c|c|c|c|c|c|c|c|c|}
\hline \multirow[t]{2}{*}{ COVID-19 theme } & \multicolumn{9}{|c|}{ Posts containing each theme per category, $\mathrm{n}(\%)^{\mathrm{a}}$} \\
\hline & $\begin{array}{l}\text { Confec- } \\
\text { tionery } \\
(n=56)^{b}\end{array}$ & $\begin{array}{l}\text { Snacks } \\
(\mathrm{n}=18)\end{array}$ & $\begin{array}{l}\text { Soft } \\
\text { drinks } \\
(n=3)\end{array}$ & $\begin{array}{l}\text { QSRs }^{\mathrm{c}} \\
(\mathrm{n}=353)\end{array}$ & $\begin{array}{l}\text { Food delivery } \\
(\mathrm{n}=52)\end{array}$ & $\begin{array}{l}\text { Beer } \\
(n=86)\end{array}$ & $\begin{array}{l}\text { Wine } \\
(n=83)\end{array}$ & $\begin{array}{l}\text { Spirits and } \\
\text { RTD }^{\mathrm{d}} \text { alcoholic } \\
\text { beverages } \\
(\mathrm{n}=34)\end{array}$ & $\begin{array}{l}\text { Bottle shops } \\
\text { and alcohol de- } \\
\text { livery } \\
(\mathrm{n}=231)\end{array}$ \\
\hline $\begin{array}{l}\text { Trading and events } \\
\text { updates }\end{array}$ & $7(13)$ & $0(0)$ & $0(0)$ & $22(6.2)$ & $7(14)$ & $1(1)$ & $15(18)$ & $4(12)$ & $70(30.3)$ \\
\hline $\begin{array}{l}\text { Home delivery and } \\
\text { take away }\end{array}$ & $2(4)$ & $0(0)$ & $0(0)$ & $197(55.8)$ & $35(67)$ & $1(1)$ & $30(36)$ & $0(0)$ & 73 (31.6) \\
\hline $\begin{array}{l}\text { Hygiene and contact } \\
\text { free }\end{array}$ & $2(4)$ & $0(0)$ & $0(0)$ & $143(40.5)$ & $17(33)$ & $0(0)$ & $12(15)$ & $4(12)$ & $26(11.3)$ \\
\hline $\begin{array}{l}\text { Community support } \\
\text { and feeling }\end{array}$ & $21(38)$ & $4(22)$ & $3(100)$ & $56(15.9)$ & $19(37)$ & $12(14)$ & $24(29)$ & $10(29)$ & $7(3.0)$ \\
\hline $\begin{array}{l}\text { Applaud health staff } \\
\text { and essential work- } \\
\text { ers }\end{array}$ & $3(5)$ & $0(0)$ & $3(100)$ & $43(12.2)$ & $5(10)$ & $0(0)$ & $4(5)$ & $0(0)$ & $3(1.3)$ \\
\hline Donations & $5(9)$ & $0(0)$ & $0(0)$ & 34 (9.6) & $4(8)$ & $2(2)$ & $9(11)$ & $6(18)$ & $3(1.3)$ \\
\hline Isolation activities & $25(45)$ & $16(89)$ & $2(67)$ & $63(17.8)$ & $3(6)$ & $48(56)$ & $44(53)$ & $14(41)$ & $150(64.9)$ \\
\hline $\begin{array}{l}\text { Consumption helps } \\
\text { coping }\end{array}$ & $5(9)$ & $2(11)$ & $0(0)$ & $26(7.4)$ & $4(8)$ & $5(6)$ & $9(11)$ & $0(0)$ & $21(9.1)$ \\
\hline $\begin{array}{l}\text { Supporting local } \\
\text { business and trading } \\
\text { partners }\end{array}$ & $0(0)$ & $0(0)$ & $0(0)$ & $11(3.1)$ & $19(37)$ & $2(2)$ & $1(1)$ & $0(0)$ & $0(0)$ \\
\hline Other & $0(0)$ & $0(0)$ & $0(0)$ & $6(1.7)$ & $0(0)$ & $11(13)$ & $2(2)$ & $2(6)$ & $6(2.6)$ \\
\hline No clear theme $\mathrm{e}^{\mathrm{e}}$ & $10(18)$ & $0(0)$ & $0(0)$ & $33(9)$ & $2(4)$ & $14(16)$ & $0(0)$ & $8(24)$ & $12(5.2)$ \\
\hline
\end{tabular}

${ }^{\mathrm{a}}$ Posts could be coded for multiple themes; therefore, the columns do not add up to $100 \%$.

${ }^{\mathrm{b}}$ All $\mathrm{n}$ values in this row represent total COVID-19-related posts.

${ }^{\mathrm{c}} \mathrm{QSR}$ : quick service restaurant.

${ }^{\mathrm{d}}$ RTD: ready-to-drink.

${ }^{\mathrm{e}}$ Indirect link to COVID-19 context (eg, using hashtags or referring to working from home).

The theme isolation activities was particularly prominent among alcohol brands as well as bottle shops and alcohol delivery services (combined), with $40 \%$ to $64 \%$ of all COVID-19-related posts from alcohol categories using this theme. The proportion of COVID-19-related posts that used the theme trading and events updates was greatest for bottle shops and alcohol delivery services (70/231, 30.3\%). Home delivery and take away-themed posts were frequently used by bottle shops and alcohol delivery services $(73 / 231,31.6 \%)$ and food delivery services $(35 / 52$,
$67 \%)$, but they were also used by QSRs $(197 / 353,55.8 \%)$ and wine brands $(30 / 83,36 \%)$.

Over a third of all posts from brands representing establishments where food is handled by staff used the hygiene and contact free theme, such as QSRs (143/353, 40.5\%) and food delivery services $(17 / 52,33 \%)$. This often included a mention of safe food handling practices and hygiene standards, an emphasis on contact-free delivery or pickup, and physical distancing requirements in stores (see Table 2 and Figure 2). 
Figure 2. Examples of posts with the hygiene and contact free (social distancing) theme.

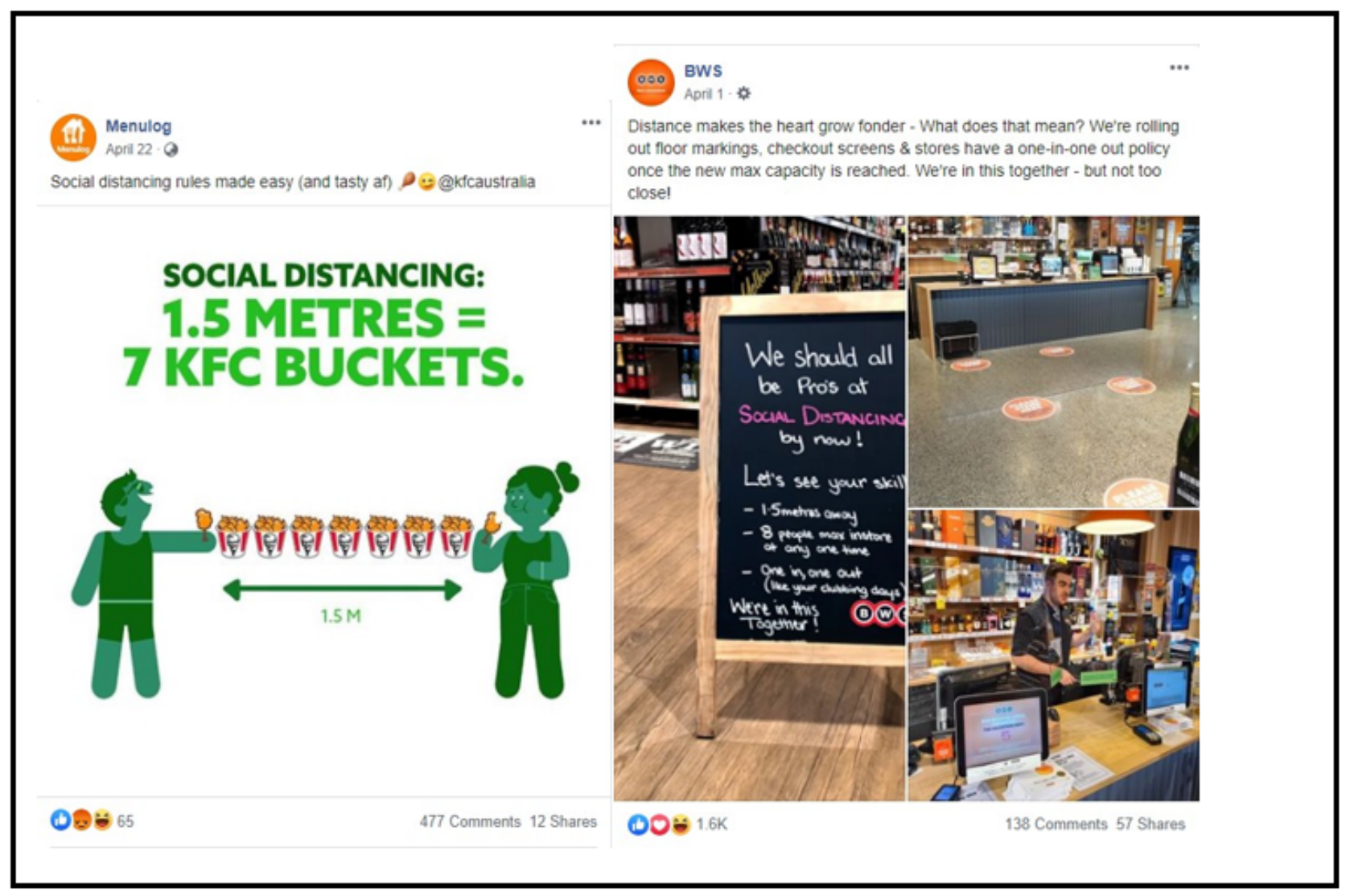

Brands also used the theme applauding health staff and essential workers for their efforts during the pandemic (QSRs: 43/353, $12.2 \%$ ) or making donations to charity or other organizations (spirits and RTD alcoholic beverages: 6/34, 18\%; wine: 9/83, 11\%; QSRs: $34 / 353,9.6 \%$ ). Approximately $5 \%$ to $10 \%$ of COVID-19-related posts across almost every category referred to the products helping people cope with isolation by creating a sense of normality or of the consumer deserving a treat in difficult times (see Table 2).

\section{Food and Alcohol Parent Companies}

A total of 16 out of 28 parent companies (57\%) were excluded from the analysis, either because the brand and parent company used the same social media account $(10 / 16,63 \%)$ or because the parent company did not have a social media account $(6 / 16$, $38 \%$ ). All 12 parent companies included in the analysis posted content that related to COVID-19. International parent companies such as Yum! Brands ( $n=194$ posts), Unilever ( $n=133$ posts), Mondelez ( $n=76$ posts), and local Australian parent company Coca-Cola Amatil ( $\mathrm{n}=70$ posts) were most prolific in posting COVID-19-related content during the 4-month period under analysis. Of all COVID-19-related posts by parent companies across all social media platforms ( $\mathrm{n}=783$ posts), $54.7 \%$ (428/783) were on Twitter and 31.2\% (244/783) were on Facebook (data not shown).

Table 5 illustrates the most frequently used themes for COVID-19-related posts by parent companies. For almost all product categories, the theme community support was highly prevalent, often expressed using hashtags such as \#InThisTogether and \#StrongerTogether. The donations theme was also frequently used across all categories. This could refer to financial donations to support relief organizations and hospitality staff funds or product donations, such as sanitizing products and food. For example, Mondelez posted that they donated US \$20 million worth of chocolate and snacks globally, mainly to health care workers and food banks. The donations theme was often combined with other frequently used themes, namely applauding health staff and essential workers. For example, a Mondelez Facebook post showed a photo of health workers with Oreos and Tang-orange, powdered drink mix-in their hands (see Table 2). 
Table 5. COVID-19-related themes of social media posts by unhealthy food, beverage, and alcohol parent companies.

\begin{tabular}{|c|c|c|c|c|c|c|c|}
\hline \multirow[t]{2}{*}{ COVID-19 theme } & \multicolumn{7}{|c|}{ Posts containing each theme per category, $\mathrm{n}(\%)^{\mathrm{a}, \mathrm{b}}$} \\
\hline & $\begin{array}{l}\text { Confectionery }(2 \\
\text { companies) } \\
(\mathrm{n}=109)^{\mathrm{c}}\end{array}$ & $\begin{array}{l}\text { Snacks (1 com- } \\
\text { pany) }(\mathrm{n}=133)\end{array}$ & $\begin{array}{l}\text { Soft drinks }(1 \\
\text { company) }(\mathrm{n}=70)\end{array}$ & $\begin{array}{l}\text { QSRs }^{\mathrm{d}}(1 \mathrm{com}- \\
\text { pany) }(\mathrm{n}=194)\end{array}$ & $\begin{array}{l}\text { Beer ( } 2 \text { compa- } \\
\text { nies) }(\mathrm{n}=23)\end{array}$ & $\begin{array}{l}\text { Wine ( } 2 \text { compa- } \\
\text { nies) }(\mathrm{n}=7)\end{array}$ & $\begin{array}{l}\text { Spirits and RTD } \\
\text { alcoholic bever- } \\
\text { ages }(3 \text { compa- } \\
\text { nies) }(n=103)\end{array}$ \\
\hline $\begin{array}{l}\text { Trading and } \\
\text { events updates }\end{array}$ & $0(0)$ & $0(0)$ & $4(6)$ & $0(0)$ & $4(17)$ & $1(14)$ & $6(5.8)$ \\
\hline $\begin{array}{l}\text { Home delivery } \\
\text { and take away }\end{array}$ & $0(0)$ & $0(0)$ & $0(0)$ & 27 (13.9) & $0(0)$ & $0(0)$ & $0(0)$ \\
\hline $\begin{array}{l}\text { Hygiene and con- } \\
\text { tact free }\end{array}$ & $1(0.9)$ & $8(6.0)$ & $5(7)$ & $39(20.1)$ & $1(4)$ & $0(0)$ & $2(1.9)$ \\
\hline $\begin{array}{l}\text { Community sup- } \\
\text { port and feeling }\end{array}$ & $70(64.2)$ & $86(64.7)$ & $30(43)$ & $114(58.8)$ & $17(74)$ & $1(14)$ & $20(19.4)$ \\
\hline $\begin{array}{l}\text { Applaud health } \\
\text { staff and essential } \\
\text { workers }\end{array}$ & $43(39.4)$ & $33(24.8)$ & $13(19)$ & $88(45.4)$ & $1(4)$ & $0(0)$ & $19(18.4)$ \\
\hline Donations & $55(50.5)$ & $60(45.1)$ & $27(39)$ & $128(66.0)$ & $6(26)$ & $2(29)$ & $67(65.0)$ \\
\hline $\begin{array}{l}\text { Isolation activi- } \\
\text { ties }\end{array}$ & $11(10.1)$ & $6(4.5)$ & $5(7)$ & $10(5.2)$ & $5(22)$ & $0(0)$ & $15(14.6)$ \\
\hline $\begin{array}{l}\text { Consumption } \\
\text { helps coping }\end{array}$ & $7(6.4)$ & $2(1.5)$ & $2(3)$ & $1(0.5)$ & $2(9)$ & $0(0)$ & $0(0)$ \\
\hline $\begin{array}{l}\text { Supporting local } \\
\text { business and } \\
\text { trading partners }\end{array}$ & $0(0)$ & $2(1.5)$ & $5(7)$ & $0(0)$ & $2(9)$ & $2(29)$ & $4(3.9)$ \\
\hline $\begin{array}{l}\text { Production of } \\
\text { sanitizing prod- } \\
\text { ucts }\end{array}$ & $3(2.8)$ & $43(32.3)$ & $17(24)$ & $0(0)$ & $1(4)$ & $0(0)$ & $24(23.3)$ \\
\hline $\begin{array}{l}\text { Health advice, in- } \\
\text { cluding mental } \\
\text { health }\end{array}$ & $15(13.8)$ & $33(24.8)$ & $2(3)$ & $0(0)$ & $4(17)$ & $4(57)$ & $19(18.4)$ \\
\hline $\begin{array}{l}\text { Maintaining es- } \\
\text { sential supply } \\
\text { chain }\end{array}$ & $25(22.9)$ & $2(1.5)$ & $3(4)$ & $0(0)$ & $1(4)$ & $0(0)$ & $0(0)$ \\
\hline
\end{tabular}

${ }^{\mathrm{a}}$ Posts could be coded for multiple themes; therefore, the columns do not add up to $100 \%$.

${ }^{\mathrm{b}}$ The categories bottle shops and alcohol delivery services and food delivery services were excluded from this table, as there were no parent companies or no parent companies with social media accounts.

${ }^{\mathrm{c}}$ All $\mathrm{n}$ values in this row represent total COVID-19-related posts.

${ }^{\mathrm{d}}$ QSR: quick service restaurant.

${ }^{\mathrm{e}} \mathrm{RTD}$ : ready-to-drink.

Posts relating to production and supply of hand sanitizer were also frequently made by parent companies that were in the business of distilling (eg, alcohol companies) or manufacturing of sanitizing products, such as soaps and bleach. These companies also often provided health advice in terms of how to clean and sanitize to prevent spread of COVID-19 (see Table 2).

The prevalence of COVID-19-related posts that provided mental health advice was highest among alcohol companies, mainly through reposting videos from DrinkWise - the Australian alcohol industry's social aspect organization-featuring a celebrity doctor warning about the use of alcohol as a coping mechanism for stress during the COVID-19 pandemic.
Some companies posted specifically to support their business or trading partners (see Table 2). Finally, 23\% of confectionery companies' posts (Mondelez and Nestlé) aimed to reassure consumers that the company was doing everything it could to maintain the "essential" food supply chain, often shown in behind-the-scenes videos of production and supply chains (see Table 2).

\section{Discussion}

\section{Principal Findings}

This is the first comprehensive and systematic analysis of the nature and extent of COVID-19-related online marketing by major alcohol and unhealthy food and beverage brands and their parent companies. We demonstrated that during a 4-month 
period (February to May 2020) of the first wave of the COVID-19 pandemic in Australia, 79\% of the top 42 alcohol and unhealthy food and beverage brands as well as all 12 parent companies posted content related to COVID-19. Approximately one-third of social media posts by brands were COVID-19 related, and the number of likes, views, and shares indicate that engagement was substantial. Australian QSRs, alcohol brands, bottle shops, and food and alcohol delivery services were the most active in posting COVID-19-related marketing during this time. While brands in the snack, confectionery, and soft drink categories were relatively less active with regard to the number of COVID-19-related posts, their parent companies were often more active. COVID-19-related social media posts most commonly related to isolation activities, particularly for alcohol brands, with approximately half of all posts using this theme. Two other common COVID-19-related themes for both brands and companies were community support, positioning themselves as "in this together" with consumers, and applauding health staff. Parent companies also frequently posted about CSR activities, such as donations of money, food, or hand sanitizer.

Our results support and extend evidence from the marketing literature that businesses often employ cause marketing on social media platforms to improve public perception of their brand over the long term [23]. We found that parent companies, in particular, frequently posted about their CSR initiatives, such as financial donations to support relief efforts; manufacturing and/or donation of hand sanitizer by alcohol companies; donating soaps and sanitizing products, such as by the snack company Unilever; and donating chocolates, such as by the confectionery companies Mondelez and Nestlé. Communicating CSR initiatives has been shown to increase positive public attitudes to alcohol and unhealthy food brands and legitimizes their consumption [31]. Such marketing not only increases sales, but creates a fertile environment to loosen current regulations or resist further regulation of the industry, as these companies are seen as "part of the solution" [31]. For example, the industry body Alcohol Beverages Australia recently called on governments to minimize "regulatory and tax burdens" in response to the impacts of COVID-19 policies on sales [32]. Providing "health advice" in relation to avoiding contraction of COVID-19 (eg, how to wash hands) and messages related to responsible consumption of alcohol was another strategy frequently used by parent companies. While these may be viewed as health promotion messages, there is evidence to suggest that this type of messaging, when propagated by the alcohol industry, actually reinforces the idea that high levels of alcohol consumption are normal [33].

Another common reason for cause marketing is to increase immediate sales and business returns by aligning with trending topics. Our results indicate that in order to effectively engage consumers, many brands and services referred to COVID-19 in their social media posts to make themselves part of the zeitgeist, for example, by providing fun isolation activities, health and hygiene advice, and claiming "we're all in this together." Additionally, we found that food and alcohol delivery services, QSRs, and bottle shops responded to the rapid changes in consumer practices during the COVID-19 pandemic (eg, buying take away instead of going to restaurants). Their posts often used COVID-19 themes related to health and safety procedures, such as contact-free pickup and delivery of food and alcohol and hygienic preparation of meals. The success of this marketing and the accompanying technological advancements in online sales is illustrated by bank card data showing that Australians spent $46.2 \%$ more in bottle shops in the week ending on May 22,2020 , compared to the same week in 2019, while spending in pubs and hotels plummeted (63\%) [34]. Given that the social media accounts included in our analysis each had thousands, or often hundreds of thousands, of followers, large numbers of people are likely exposed to these posts, making social media posts a very efficient form of (unpaid) advertising.

"COVID-washing" of social media posts by Big Food and Big Alcohol is propagated to ultimately further increase sales and consumption of their unhealthy products and is in direct contrast with the goal of "building back better" from COVID-19 [35]. Alcohol consumption and unhealthy food and beverage consumption are both major risk factors for excess weight gain and obesity, which in turn are risk factors for comorbidities and mortality from COVID-19 [4]. Reducing population levels of alcohol and unhealthy food consumption will not only protect against the ongoing threat from COVID-19 and other pandemics in the future but is also vital for maintaining physical and mental health during pandemics and associated times of restricted movement. Regulating the marketing of these unhealthy products is an important step toward achieving this public health goal.

\section{Limitations}

Our study did not capture posts from smaller brands and companies. However, this is the first study to comprehensively describe the nature and extent of "COVID-washing" on social media platforms. A strength of our analysis is that we systematically captured all posts on social media platforms from the top brands $(n=42)$ and parent companies $(n=12)$, by market share, in Australia across a 4-month period during the COVID-19 pandemic. While examining all food and alcohol posts from social media platforms would provide a more accurate indication of COVID-19 marketing breadth, it would miss the depth that we were able to capture by focusing on the largest brands and companies. Another limitation of this study is that it only included publicly available marketing on four social media platforms and has missed posts on other social media platforms, including those where young people, who are more vulnerable to the effects of marketing, are active, such as Snapchat and TikTok. Our initial scoping of posts by the brands and companies included in our study suggested that the brands and companies under analysis did not have public accounts on these social media platforms; however, further work is required to better understand how these social media platforms are used by alcohol and food companies to engage consumers, including during times of crisis. A further limitation is that we were unable to determine from our analysis what the reach and actual exposure levels to these posts were. This information is only available to the marketers. However, the number of followers of active brand accounts and the level of engagement with COVID-19-related posts suggest that reach was quite high. Finally, this study only captured a portion of the marketing material created by these brands. We included public posts on 
official brand and company accounts, but not user-generated content, which is now an integral part of brands' and companies' marketing campaigns (eg, the use of influencers). We also did not capture paid advertisements, as companies are unlikely to post ads on their public pages. Thus, the practices we have identified may well be much more extensive and culturally embedded than what we describe here. It is important that future studies are designed to monitor both covert and overt marketing techniques.

\section{Conclusions}

"COVID-washing" by Big Food and Big Alcohol is both common and concerning. Brands and companies have strategically designed their marketing campaigns to positively align with the COVID-19 pandemic to increase brand loyalty and sales and potentially to influence and oppose regulation. This is problematic, as consumption of alcohol and unhealthy foods are directly or indirectly associated with poorer COVID-19-related outcomes; they also negatively impact physical and mental health beyond the pandemic. The implementation of comprehensive regulations to restrict unhealthy food and alcohol marketing, as recommended by the World Health Organization [36,37], is particularly acute in the COVID-19 context and is urgently required to "build back better" in a post-COVID-19 world.

\section{Acknowledgments}

This study would not have been possible without the support of the Victorian Health Promotion Foundation (VicHealth), which funded this study. KB is also supported by a Heart Foundation Future Leader Fellowship (102047).

\section{Authors' Contributions}

FM, NC, CZ, KC, ES, JM, AP, and KB conceived and designed the study. FM, RB, and JB collected and coded the data. FM performed the analysis. FM, RB, JB, and $\mathrm{KB}$ interpreted the data and prepared the original manuscript. All authors reviewed and approved the final version of the manuscript. Two of the study authors (KC and ES) are employees at VicHealth and contributed to the paper as stated above.

\section{Conflicts of Interest}

None declared.

\section{Multimedia Appendix 1}

Inclusion of brands and parent companies in the audit.

[DOCX File, 22 KB-Multimedia Appendix 1]

\section{References}

1. Rolling updates on coronavirus disease (COVID-19). World Health Organization. 2020 Jul 30. URL: https://www.who.int/ emergencies/diseases/novel-coronavirus-2019/events-as-they-happen [accessed 2020-11-20]

2. Coronavirus disease (COVID-19). World Health Organization. 2020 Oct 12. URL: https://www.who.int/emergencies/ diseases/novel-coronavirus-2019/question-and-answers-hub/q-a-detail/coronavirus-disease-covid-19 [accessed 2020-11-20]

3. Yang J, Tian C, Chen Y, Zhu C, Chi H, Li J. Obesity aggravates COVID-19: An updated systematic review and meta-analysis. J Med Virol 2020 Nov 17:1-13 [FREE Full text] [doi: 10.1002/jmv.26677] [Medline: 33200825]

4. GBD 2013 Risk Factors Collaborators. Global, regional, and national comparative risk assessment of 79 behavioural, environmental and occupational, and metabolic risks or clusters of risks in 188 countries, 1990-2013: a systematic analysis for the Global Burden of Disease Study 2013. The Lancet 2015;386(10010):2287-2323. [doi: 10.1016/S0140-6736(15)00128-2] [Medline: 26364544]

5. Sarkar D, Jung MK, Wang HJ. Alcohol and the immune system. Alcohol Res 2015;37(2):153-155 [FREE Full text]

6. Rhodes A. National Child Health Poll. COVID-19 Pandemic: Effects on the Lives of Australian Children and Families. Melbourne, Australia: The Royal Children's Hospital; 2020 Jul. URL: https://www.rchpoll.org.au/wp-content/uploads/2020/ 07/nchp-poll18-report-covid.pdf [accessed 2020-11-16]

7. Keyes KM, Hatzenbuehler ML, Hasin DS. Stressful life experiences, alcohol consumption, and alcohol use disorders: The epidemiologic evidence for four main types of stressors. Psychopharmacology (Berl) 2011 Nov;218(1):1-17 [FREE Full text] [doi: 10.1007/s00213-011-2236-1] [Medline: 21373787]

8. Kushner M, Abrams K, Borchardt C. The relationship between anxiety disorders and alcohol use disorders: A review of major perspectives and findings. Clin Psychol Rev 2000 Mar;20(2):149-171. [doi: 10.1016/s0272-7358(99)00027-6] [Medline: 10721495]

9. Pool E, Delplanque S, Coppin G, Sander D. Is comfort food really comforting? Mechanisms underlying stress-induced eating. Food Res Int 2015 Oct 01;76:207-215. [doi: 10.1016/j.foodres.2014.12.034]

10. de Goeij MCM, Suhrcke M, Toffolutti V, van de Mheen D, Schoenmakers TM, Kunst AE. How economic crises affect alcohol consumption and alcohol-related health problems: A realist systematic review. Soc Sci Med 2015 Apr;131:131-146. [doi: 10.1016/j.socscimed.2015.02.025] [Medline: 25771482] 
11. Kemp E, Kennett-Hensel P, Williams K. The calm before the storm: Examining emotion regulation consumption in the face of an impending disaster. Psychol Mark 2014 Oct 09;31(11):933-945. [doi: 10.1002/mar.20744]

12. Curtis A, Vandenberg B, Mayshak R, Coomber K, Hyder S, Walker A, et al. Alcohol use in family, domestic and other violence: Findings from a cross-sectional survey of the Australian population. Drug Alcohol Rev 2019 May;38(4):349-358. [doi: 10.1111/dar.12925] [Medline: 30942525]

13. Lai J, Hiles S, Bisquera A, Hure A, McEvoy M, Attia J. A systematic review and meta-analysis of dietary patterns and depression in community-dwelling adults. Am J Clin Nutr 2014 Jan;99(1):181-197 [FREE Full text] [doi: 10.3945/ajen.113.069880] [Medline: 24196402]

14. O'Neil A, Quirk SE, Housden S, Brennan SL, Williams LJ, Pasco JA, et al. Relationship between diet and mental health in children and adolescents: A systematic review. Am J Public Health 2014 Oct;104(10):e31-e42. [doi: 10.2105/AJPH.2014.302110] [Medline: 25208008]

15. Hamer M, Kivimäki M, Gale C, Batty G. Lifestyle risk factors, inflammatory mechanisms, and COVID-19 hospitalization: A community-based cohort study of 387,109 adults in UK. Brain Behav Immun 2020 Jul;87:184-187 [FREE Full text] [doi: 10.1016/j.bbi.2020.05.059] [Medline: 32454138]

16. Armstrong G, Adam S, Denize S, Kotler P. Principles of Marketing. 7th edition. Melbourne, Australia: Pearson Australia; 2018.

17. Carah N. Alcohol corporations and marketing in social media. In: Lyons AC, McCreanor T, Goodwin I, Moewaka Barnes H, editors. Youth Drinking Cultures in a Digital World: Alcohol, Social Media and Cultures of Intoxication. New York, NY: Routledge; 2017:115-131.

18. Cairns G, Angus K, Hastings G, Caraher M. Systematic reviews of the evidence on the nature, extent and effects of food marketing to children. A retrospective summary. Appetite 2013 Mar;62:209-215. [doi: 10.1016/j.appet.2012.04.017] [Medline: 22561190]

19. Pettigrew S, Jongenelis M, Jongenelis G, Pierce H, Stafford J, Keric D. Get them laughing to get them drinking: An analysis of alcohol advertising themes across multiple media in Australia. J Stud Alcohol Drugs 2020 May;81(3):311-319. [doi: 10.15288/jsad.2020.81.311]

20. Collin J, Raston R, Hill S. Signalling Virtue, Promoting Harm: Unhealthy Commodity Industries and COVID-19. Edinburgh, Scotland: NCD Alliance, SPECTRUM; 2020. URL: https://ncdalliance.org/sites/default/files/resource files/

Signalling\%20Virtue\%2C\%20Promoting\%20Harm_Sept2020_FINALv.pdf [accessed 2020-11-30]

21. Rego MM. The Impact of Cause-Related Marketing on Global Consumers: A Meta-Analysis [doctoral dissertation]. Storrs, CT: University of Connecticut; 2017. URL: https://opencommons.uconn.edu/cgi/viewcontent. cgi? article=7910\&context=dissertations [accessed 2021-03-02]

22. Chernev A, Blair S. Doing well by doing good: The benevolent halo of corporate social responsibility. J Consum Res 2015 Apr 01;41(6):1412-1425 [FREE Full text] [doi: 10.1086/680089]

23. Araujo T, Kollat J. Communicating effectively about CSR on Twitter. Internet Res 2018 Apr 04;28(2):419-431 [FREE Full text] [doi: 10.1108/intr-04-2017-0172]

24. Mart S, Giesbrecht N. Red flags on pinkwashed drinks: Contradictions and dangers in marketing alcohol to prevent cancer. Addiction 2015 Oct;110(10):1541-1548. [doi: 10.1111/add.13035] [Medline: 26350708]

25. Hendriks H, Wilmsen D, van Dalen W, Gebhardt WA. Picture me drinking: Alcohol-related posts by Instagram influencers popular among adolescents and young adults. Front Psychol 2019;10:2991 [FREE Full text] [doi: 10.3389/fpsyg.2019.02991] [Medline: 32038379]

26. Bragg M, Pageot YK, Amico A, Miller AN, Gasbarre A, Rummo PE, et al. Fast food, beverage, and snack brands on social media in the United States: An examination of marketing techniques utilized in 2000 brand posts. Pediatr Obes 2020 May;15(5):e12606. [doi: 10.1111/ijpo.12606] [Medline: 31875654 ]

27. Krippendorff K. Content Analysis: An Introduction to its Methodology. 2nd edition. Thousand Oaks, CA: SAGE Publications; 2004.

28. Brand Shares Australia 2019. Euromonitor International. URL: https://www.euromonitor.com/australia [accessed 2021-05-08]

29. Monteiro CA, Cannon G, Levy R, Moubarac J, Jaime P, Martins AP, et al. NOVA. The star shines bright. World Nutr 2016;7(1-3):28-38 [FREE Full text]

30. Australian Competition and Consumer Commission. Digital Platforms Inquiry. Canberra, Australia: Commonwealth of Australia; 2019 Jun. URL: https://www.accc.gov.au/system/files/Digital\%20platforms\%20inquiry\%20-\%20final\%20report. pdf [accessed 2020-09-10]

31. Mialon M, McCambridge J. Alcohol industry corporate social responsibility initiatives and harmful drinking: A systematic review. Eur J Public Health 2018 Aug 01;28(4):664-673 [FREE Full text] [doi: 10.1093/eurpub/cky065] [Medline: 29697783]

32. Worst month on record for Australian beer, wine, spirits producers: ABA covid report. Alcohol Beverages Australia. 2020. URL: https://www.alcoholbeveragesaustralia.org.au/ worst-month-on-record-for-australian-beer-wine-spirits-producers-aba-covid-report/ [accessed 2020-09-23]

33. Pettigrew S, Biagioni N, Daube M, Stafford J, Jones S, Chikritzhs T. Reverse engineering a 'responsible drinking' campaign to assess strategic intent. Addiction 2016 Jun;111(6):1107-1113. [doi: 10.1111/add.13296] [Medline: 27157907] 
34. CommBank card spending data shows continued improvement. Commonwealth Bank of Australia. 2020 May 26. URL: https://www.commbank.com.au/guidance/business/commbank-card-spending-data-shows-continued-improvement-202005. $\underline{\mathrm{html}}$ [accessed 2020-09-22]

35. Building back better: A sustainable, resilient recovery after COVID-19. OECD. 2020 Jun 05. URL: http://www.oecd.org/ coronavirus/policy-responses/building-back-better-a-sustainable-resilient-recovery-after-covid-19-52b869f5/ [accessed 2020-09-23]

36. Set of Recommendations on the Marketing of Foods and Non-Alcoholic Beverages to Children. Geneva, Switzerland: World Health Organization; 2010. URL: https://apps.who.int/iris/bitstream/handle/10665/44416/9789241500210 eng.pdf [accessed 2020-09-22]

37. Global Status Report on Alcohol and Health. Geneva, Switzerland: World Health Organization; 2014. URL: https://apps. who.int/iris/bitstream/handle/10665/112736/9789240692763 eng.pdf?sequence=1 [accessed 2020-09-22]

\author{
Abbreviations \\ CSR: corporate social responsibility \\ QSR: quick service restaurant \\ RTD: ready-to-drink \\ VicHealth: Victorian Health Promotion Foundation
}

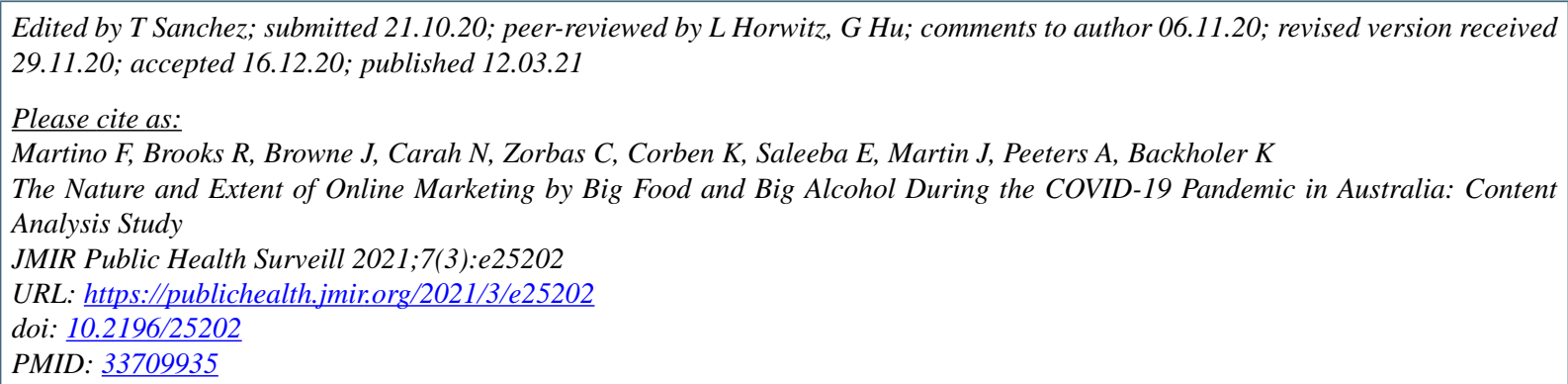

(CFlorentine Martino, Ruby Brooks, Jennifer Browne, Nicholas Carah, Christina Zorbas, Kirstan Corben, Emma Saleeba, Jane Martin, Anna Peeters, Kathryn Backholer. Originally published in JMIR Public Health and Surveillance (http://publichealth.jmir.org), 12.03.2021. This is an open-access article distributed under the terms of the Creative Commons Attribution License (https://creativecommons.org/licenses/by/4.0/), which permits unrestricted use, distribution, and reproduction in any medium, provided the original work, first published in JMIR Public Health and Surveillance, is properly cited. The complete bibliographic information, a link to the original publication on http://publichealth.jmir.org, as well as this copyright and license information must be included. 